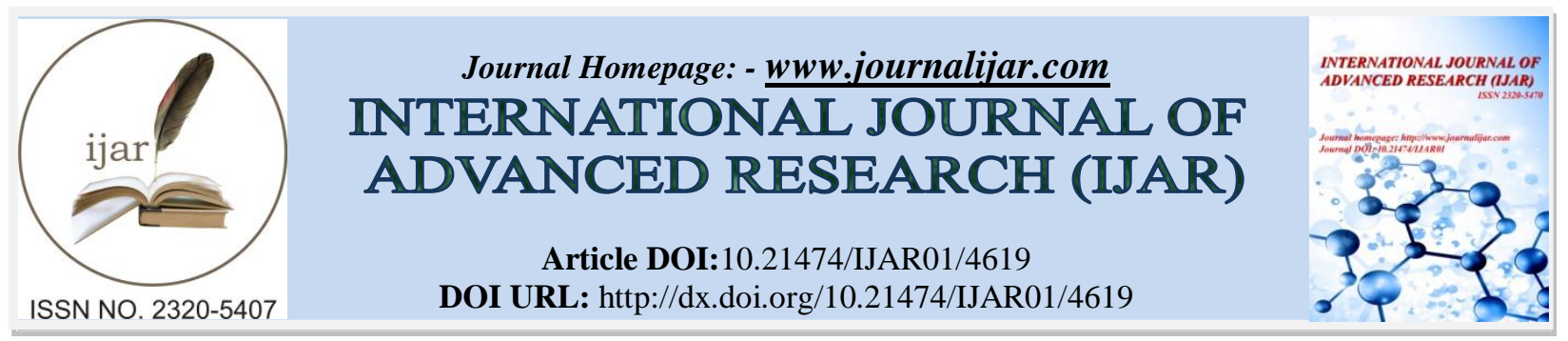

RESEARCH ARTICLE

\title{
EFFECT OF INDIGENOUS SUBSTANCES IN PARINAAM SHOOLA W.S.R. TO DUODENAL ULCER.
}

Dr. Neelam Sajwan ${ }^{1}$ and Dr. Swapnil Singhai ${ }^{2}$.

1. Assistant Professor cum Consultant Department of Shalya Tantra Uttarakhand Ayurved University, Dehradun U.K.

2. Professor - Kayachikitsa Uttarakhand Ayurved University, Dehradun, U.K.

\section{Manuscript Info}

(.........................

\section{Manuscript History}

Received: 26 April 2017

Final Accepted: 28 May 2017

Published: June 2017

Key words:-

Ayurveda, Duodenal ulcer, Parinaam shoola, Patoladi ghanvati.

\section{Abstract}

A duodenal ulcer is a type of ulcer that occurs in the duodenum, the beginning of the small intestine. The most common cause of duodenal ulcer is a stomach infection associated with the Helicobacter pylori bacteria. Duodenal ulcers are eroded areas in the lining of duodenum, which result in abdominal pain, possible bleeding and other gastrointestinal symptoms. Other risk factors for duodenal ulcers include overuse of alcohol, tobacco, and medications such as aspirin and non-steroidal anti-inflammatory drugs. Severe illness has also been implicated as a risk factor in the development of duodenal ulcer. The signs and symptoms of duodenal ulcer can be constant or sporadic pain, heartburn, severe nausea and vomiting. Patients with duodenal ulcer will complain of pain that awakens them from sleep. Treatment focused on hospitalization, bed rest, and prescription of special bland foods. Antacids and medications that block acid production became the standard of therapy. Despite this treatment, there was a high recurrence of ulcers. Patients with $H$. pylori infection can be treated with antibiotics.

In Ayurveda, the symptoms, etiopathogenesis of duodenal ulcer resembles with Parinaam Shoola. Treatment includes administration of Sanshodhana, Sanshamana, Nidan Parivarjana, Pathya-apathya and prevention of recurrences. The Patoladi Ghanvati along with some indigenous drugs is found to be effective in combating this disease.

Total 30 patients diagnosed as Parinaam Shoola (Duodenal Ulcer) of any socio-economic status, age group of 15-70 years and irrespective of sex were randomly selected. The drugs Patoladi Ghanvati was orally given for three month of duration.

Patoladi Ghanvati was effective in alleviating the symptoms of Parinaam Shoola. It was observed that the drug is especially effective in early cases of Parinaam Shoola. This beneficial effect of trial drug may be due to its Deepan, Pachan, Pitta-sarak, Udarshool-nashak, Vatanulomak, Anti-inflamatory, Anti-Ulcer, Anti-oxidant, Anti-Stress and Anti-Spasmodic properties.

Copy Right, IJAR, 2017,. All rights reserved. 


\section{Introduction:-}

Parinaam Shoola vis-à-vis gastrointestinal disorders especially Duodenal Ulcer is a common problem. It is the leading cause of physician visits worldwide. An ulcer on the mucosa of the duodenum caused by the action of the gastric juice is known as duodenal ulcer. ${ }^{[1]}$ Pre-existing Helicobacter pylori infection increases the risk for the subsequent development of either duodenal or gastric ulcer disease. The interplay of etiological factors in the pathogenesis of idiopathic peptic ulcer disease is poorly defined but may include a genetic predisposition, altered acid secretion, rapid gastric emptying, defective mucosal defense mechanisms, psychological stress, and smoking. ${ }^{[2]}$ Smoking increases acid secretion reduces prostaglandin and bicarbonate production, and decreases mucosal blood flow, delays the healing of gastric and duodenal ulcers. ${ }^{[3]}$

A higher prevalence occurs in areas where the diet is principally polished milled rice, refined wheat or maize, corn flour, sorghum vulgar, yams, sugar, amaranths, brinjal, peanut oil, some pulses, cassava, sweet potato or green bananas and skimmed milk. ${ }^{[4-5]}$

A number of endocrine dysfunctions such as Zollinger-Ellison syndrome, Cushing`s syndrome, Parathyroid tumor, Bronchial CA, Multiple adenoma syndrome, Antral G - Cell hyper-function \& or hyperplasia can also lead to duodenal ulceration. ${ }^{[6]}$

Majorrisk factors for duodenal ulcer include smoking, low-dose $(\leq 160 \mathrm{mg})$ aspirin use \&H. pylori infection. ${ }^{[7]}$

Most patients with duodenal ulcers have impaired duodenal bicarbonate secretion, which has also proven to be caused by $H$. pylori because its eradication reverses the defect. The combination of increased gastric acid secretion and reduced duodenal bicarbonate secretion lowers the $\mathrm{pH}$ in the duodenum, which promotes the development of gastric metaplasia (the presence of gastric epithelium in the first portion of the duodenum). $H$ pylori infection in areas of gastric metaplasia induces duodenitis and enhances the susceptibility to acid injury, thereby predisposing to duodenal ulcers. ${ }^{[8-9]}$

Most duodenal ulcers occur in the first part of the duodenum. A chronic ulcer penetrates the mucosa \& into the muscle coat, leading to fibrosis. These ulcers vary in shape- circular, oval cresentric, pear shaped or triangular. The ulcer has a punched out appearance, the margins are overhanging. The granulating base is covered with mucopurulent debris. Though the muscle coat is always reached, the depth of the ulcer depends on the degree of penetration. Multiple duodenal ulcers occur in $10-15 \%$ of cases. ${ }^{[10]}$ Patients with duodenal ulcer will complain of pain that awakens them from sleep. Duodenal ulcer pain would manifest mostly 2-3 hours after the meal, when the stomach begins to release digested food and acid into the duodenum. The other symptoms are bloating and abdominal fullness, water brash (rush of saliva after an episode of regurgitation to dilute the acid in esophagus although this is more associated with gastroesophageal reflux disease), nausea, malena (tarry, foul-smelling feces due to oxidized iron from hemoglobin). ${ }^{[1-12]}$

The most significant complication is hemorrhage, perforation, and probably obstruction appears in a random fashion during an ulcer's course. ${ }^{[13]}$ Treatment focused on hospitalization, bed rest, and prescription of special bland foods. Antacids and medications that block acid production became the standard of therapy. Despite this treatment, there was a high recurrence of ulcers. Patients with $H$. pylori infection can be treated with antibiotics.

Acharya Madhava has defined Parinaam Shoola to be a disease characterized by pain during the digestion of food.

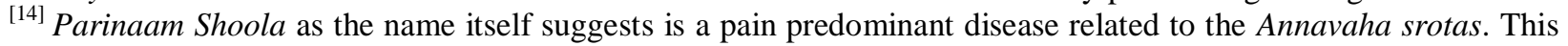
Srotas is the basis for the very subsistence of life. The cardinal feature of this disease is Ahara jiryamana kala shoola and the site affected is Grahani. Hence, it torments the person at every mealtime and is a source of constant discomfort. It predisposes to an overall reduction in the physical activities of the person in its chronic course. By virtue of all the above factors, it needs prompt attention.

As per Madhav Nidaan, Parinaam Shoola has also been described as Durvigyeya Mahagada. ${ }^{[15]}$ It is not described in Brihat-trayee. The gastrointestinal examination like Barium meal and Endoscopy aid a confirmatory diagnosis and treatment at the earliest.

The efficacy of Patoladi gana ${ }^{[16]}$ along with four indigenous substances-Mulethi, Nimba, Chitraka \& Sunthi in combating this disease is being studied. 
Even though considerable research work is carried out on Parinaam Shoola using single drugs as well as formulations, till date, no study has been carried out on the above formulation regarding their efficacy in treating Parinaam Shoola, hence it is taken up for the present study.

In the clinical study, 30 patients diagnosed as Parinaam Shoola have been registered and an endoscopic evaluation of all the patients has also been carried out to correlate the modern aspect of this disease. The patients are selected and treated with the above formulations. The pre-study and post-study data are observed and analyzed statistically. It is hoped that this study will add to the existing knowledge and result in better and efficient management of Parinaam Shoola.

\section{Clinical Study:-}

\section{Material and Method:-}

The clinical study is to evaluate the efficacy of Patoladi Ghanvati (oral) in the management of Parinaam shoola. It comprises of materials \& methods, observations, results with statistical analysis. In the present study the diagnosed cases of Parinaam shoolawere randomly selected and subjected to clinical trial. The methodology of clinical trial \& observations are as follows

\section{Source of Data:-}

Patients attending the Shalya and Kayachikitsa O.P.D. of Rishikul state P.G. Ayurvedic College and hospital, Haridwar, were taken as the material for the study.

Criteria for selection of patients:-

Method of collection of data:-Patients with classical signs \& symptoms of Parinaam Shoola will be randomly selected for the study, irrespective of age, sex, religion, occupation etc.

Sample size - Single trial group of 30 patients was taken for the study to evaluate the efficacy of the trial drug.

\section{Inclusion Criteria:-}

1. Age $15-70$ years.

2. Patients with sign \& symptoms of Parinaam shool (Duodenal Ulcer).

\section{Exclusion Criteria:-}

1. Age $>70$ years

2. Recurrent episodes of severe pain restricting the patients from daily routine work.

3. Associated complication (Hour glass stomach or pyloric stenosis )

4. Immuno-compromised patient (i.e. HIV, Tuberculosis etc)

5. Other complicated disorders (i.e. Zolinger-Ellison syndrome, liver cirrhosis etc)

\section{Informed consent:-}

An informed written consent was obtained from all included subjects. The consent form was prepared in accordance with the guidelines of WHO Research Ethics Review Committee (ERC).

\section{Criteria for Diagnosis:-}

Patients were selected on the basis of endoscopic evaluation.

\section{Investigation:-}

\section{Routine investigation}

1. Blood Examination: $\mathrm{Hb} \%$, TLC, DLC, ESR, Blood group / Rh factor, Blood sugar (fasting \& PP), CT, BT, LFT, HIV, HbsAg .

2. Urine examination: Routine \& microscopy.

3. Stool examination: For ova, cyst, pus, occult blood etc .

\section{Specific Investigation:-}

1. UGI Endoscopy

2. Biopsy ( RUT ), for H.Pylori detection. 


\section{Criteria For selection of Drug:-}

For the present study, the trial drug is Patoladi Ghanvati containing Patoladi ganaalong with Mulethi, Nimb, Chitrak and Sunthi is taken. Maximum ingredients of Patoladi Ghanvati have Deepan, Pachan, Pitta-sarak, Udarshoola-nashak, Krimighana, Vatanulomak, Anti-inflammatory, Anti-oxidant, Anti-spasmodic, Anti-ulcer properties, which may be helpful to cure the cardinal symptoms of Parinaam Shoola.

Management:- Patoladi Ghanvati in a dose of 2 tabs (each of 500mg), thrice a day, with honey, before meal.

Duration:- Total duration of the treatment was 90 days.

Dietary advice:- All the patients were advised to include Honey, Green tea, cabbage, tomato, cucumber, ginger, sprouts, amla, soyabean and apple in their routine and avoid tea, coffee, smoking, alcohol and spicy diet, physical and mental stress.

Criteria for Assessment:- The patients were assessed on the basis of the following parameters before \& after the treatment.

Subjective parameters:- The parameters were graded arbitrarily as follows:

Periodicity of pain:-

\begin{tabular}{|c|c|c|c|c|c|c|c|c|c|c|c|c|c|c|c|c|c|c|}
\hline Sr. No. & Scoring & $\mathrm{C}$ & & $\mathrm{r}$ & & $\mathrm{i}$ & & & & & c & & & $\mathrm{r}$ & $\mathrm{i}$ & & & $\mathrm{a}$ \\
\hline 1 & 0 & $\mathrm{~N}$ & & & o & & & & & $\mathrm{p}$ & & & $\mathrm{a}$ & & $\mathrm{i}$ & & & $\mathrm{n}$ \\
\hline 2 & 1 & $\mathrm{O}$ & $\mathrm{c}$ & & $\mathrm{c}$ & $\mathrm{a}$ & 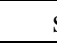 & & $\mathrm{i}$ & & o & $\mathrm{n}$ & & $\mathrm{a}$ & 1 & 1 & & $\mathrm{y}$ \\
\hline 3 & 2 & $\mathrm{O}$ & $\mathrm{c}$ & $\mathrm{e}$ & $\mathrm{o}$ & $\mathrm{r}$ & $\mathrm{t}$ & $\mathrm{w}$ & $\mathrm{i}$ & $\mathrm{c}$ & $\mathrm{e}$ & $\mathrm{i}$ & $\mathrm{n}$ & $\mathrm{a}$ & $\mathrm{w}$ & $\mathrm{e}$ & $\mathrm{e}$ & $\mathrm{k}$ \\
\hline 4 & 3 & $3-4 t$ & 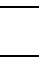 & & $\mathrm{m}$ & $\mathrm{e}$ & $\mathrm{S}$ & & $\mathrm{i}$ & & $\mathrm{n}$ & & $\mathrm{a}$ & & $\mathrm{W}$ & $\mathrm{e}$ & $\mathrm{e}$ & \\
\hline
\end{tabular}

Nausea \& vomiting:-

\begin{tabular}{|c|c|c|c|c|c|c|c|c|c|c|c|c|c|c|c|c|c|c|c|}
\hline Sr. No. & Scoring & $\mathrm{C}$ & & & $\mathrm{r}$ & & $\mathrm{i}$ & & & $\mathrm{t}$ & & $\mathrm{e}$ & & & $\mathrm{r}$ & & $\mathrm{i}$ & & \\
\hline 1 & 0 & $\mathrm{~N}$ & $\mathrm{O}$ & & $\mathrm{n}$ & $\mathrm{a}$ & $\mathrm{u}$ & $\mathrm{s}$ & $\mathrm{e}$ & $\mathrm{a}$ & $\&$ & & $\mathrm{v}$ & $\mathrm{o}$ & $\mathrm{m}$ & $\mathrm{i}$ & $\mathrm{t}$ & $\mathrm{i}$ & \\
\hline 2 & 1 & $\mathrm{~N}$ & & $\mathrm{a}$ & & $\mathrm{u}$ & & $\mathrm{s}$ & & $\mathrm{e}$ & $\mathrm{a}$ & & & $\mathrm{o}$ & & $\mathrm{n}$ & & 1 & \\
\hline 3 & 2 & $\mathrm{~N}$ & $\mathrm{a}$ & $\mathrm{d}$ & $\mathrm{e}$ & $\mathrm{a}$, & $\mathrm{o}$ & $\mathrm{c}$ & c & $\begin{array}{lll}a & s & i \\
\end{array}$ & $\mathrm{O}$ & $\mathrm{n} \mathrm{a}$ & 11 & $\mathrm{y}$ & $\mathrm{v}$ & $\mathrm{o} \quad \mathrm{m}$ & $1 \mathrm{i}$ & $\mathrm{t}$ & \\
\hline 4 & 3 & $\mathrm{~N}$ & $\mathrm{a}$ & $\mathrm{u} \quad \mathrm{s}$ & $\mathrm{e}$ & & & o & 11 & $\begin{array}{ll}\mathrm{o} & \mathrm{W}\end{array}$ & $\mathrm{e}$ & $\mathrm{d}$ & $\mathrm{b}$ & & & $\mathrm{o} \quad \mathrm{m}$ & & $\mathrm{t} i$ & \\
\hline
\end{tabular}

Pain in relation with food:-

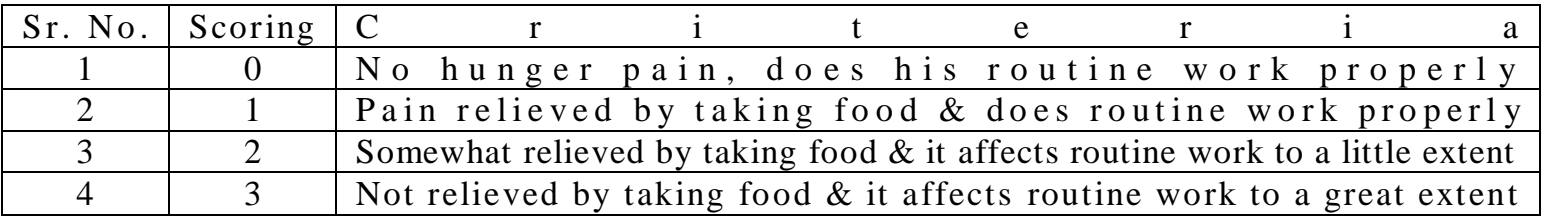

Epigastric Pain:-

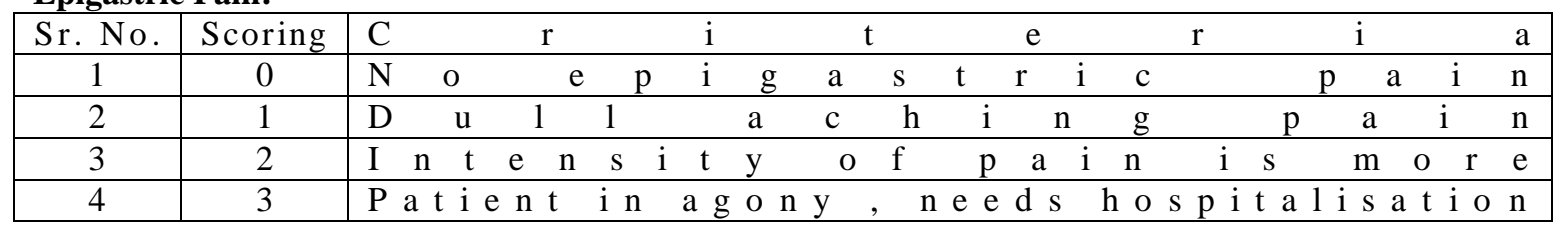

Acid regurgitation:-

\begin{tabular}{|c|c|c|c|c|c|c|c|c|c|c|c|c|c|c|c|c|c|c|c|c|c|c|c|c|}
\hline Sr. No. & Scoring & $\mathrm{C}$ & & & $\mathrm{r}$ & & & $\mathrm{i}$ & & & & $\mathrm{t}$ & & & $\mathrm{e}$ & & & $\mathrm{r}$ & & & & i & & \\
\hline 1 & 0 & $\mathrm{~N}$ & $\mathrm{o}$ & $\mathrm{O}$ & $\mathrm{r}$ & & & $\mathrm{a}$ & $\mathrm{n}$ & $\mathrm{s}$ & $\mathrm{i}$ & $\mathrm{e}$ & $\mathrm{n}$ & & $\mathrm{r}$ & $\mathrm{e}$ & $\begin{array}{ll}\mathrm{g} & \mathrm{u} \\
\mathrm{g}\end{array}$ & $\mathrm{r}$ & $\mathrm{g}$ & $\mathrm{i}$ & & $\begin{array}{lll} & t & i\end{array}$ & o & $\mathrm{n}$ \\
\hline 2 & 1 & $\mathrm{O}$ & $\mathrm{c}$ & $\mathrm{c}$ & $\mathrm{a}$ & $\mathrm{s}$ & $\mathrm{i}$ & 0 & $\mathrm{n}$ & $\mathrm{a}$ & 1 & & $\mathrm{r}$ & $\mathrm{e}$ & $\mathrm{g}$ & $\mathrm{u}$ & $r$ & $\mathrm{~g}$ & $\mathrm{i}$ & $\mathrm{t}$ & $\mathrm{a}$ & $\mathrm{t} \quad \mathrm{i}$ & o & $\mathrm{n}$ \\
\hline 3 & 2 & $\mathrm{O}$ & $\mathrm{n} \mathrm{c}$ & $\mathrm{e}$ & $\mathrm{o}$ & $r$ & & $\mathrm{w}$ & & $\mathrm{e}$ & $\mathrm{a}$ & & & $\mathrm{y}$ & & & & & & $\mathrm{t}$ & 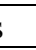 & $\mathrm{r}$ e 1 & $\mathrm{ie}$ & $\mathrm{f}$ \\
\hline
\end{tabular}

Data Analyzing Methods - Statistical Methods - The data generated in the clinical study was analyzed by applying student ' $\mathrm{t}$ ' test. The obtained results were interpreted as -

- Not significant (NS) $\quad: \quad P>0.05$

- Significant (S) $\quad: \quad \mathrm{P}<0.05$ or $\mathrm{p}<0.01$ 
- Highly significant (HS) : $\quad \mathrm{P} \leq 0.001$

Follow up period:-All the cases were treated up to the relief in the symptoms \&/or signs of the disease. Assessment of the patient was carried out on every $15^{\text {th }}$ day in three months of period.

Total Assessment of the Results:-

The treatment effect will be assessed weekly on the basis of the relief of signs and symptoms of the disease on scoring pattern by a specially designed proforma.

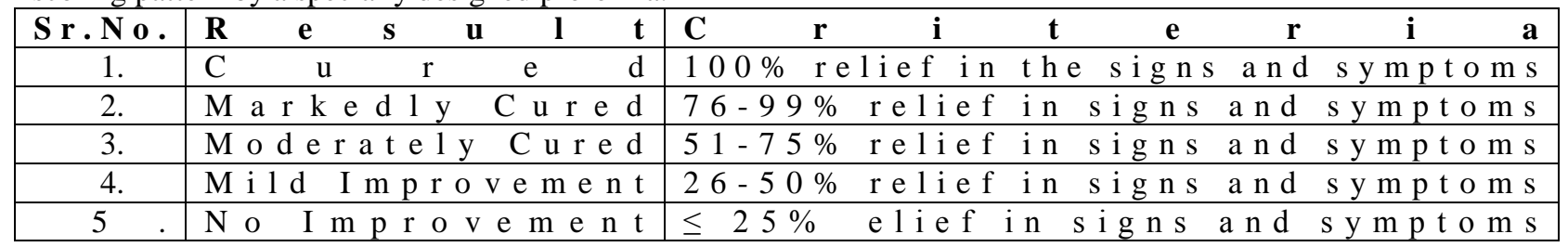

\section{Observation:-}

The effect of Patoladi Gana along with four indigenous substances - Mulethi, Nimba, Chitraka and Sunthi was studied in 30 patients suffering from Parinaam Shoola (Duodenal Ulcer), fulfilling the inclusion criteria. The observations were as follows - Maximum numbers of patients were from 31-40 years. Male patients were 17 $(56.66 \%)$ reported in the clinical trial. Most of the patients $26(86.66 \%)$ were from hindu community. Educational status of maximum patients $7(23.33 \%)$ was higher secondary. 15 patients $(50 \%)$ were related to service class. Maximum number of patients i.e. $19(63.33 \%)$ were married. 18 patients $(60 \%)$ were related to the middle class family. 10 patients $(33.33 \%)$ were having tea and coffee addiction followed by alcohol addiction 26.66\%. Maximum 14 patients $(66.66 \%)$ were having mixed diet. Maximum 12 patients $(40 \%)$ were having good appetite. 18 patients $(60 \%)$ were having irregular bowel habit. Sleep pattern of maximum patients $20(66.66 \%)$ was disturbed. 17 patients $(56.66 \%)$ were performing no physical exercise. Vataja-pittaja prakriti was observed in maximum 12 patients (40\%). Blood group O+ was noticed in maximum 11 patients (36.66\%). Family history of Parinaam Shoola was present in only 9 patients $(30 \%)$.

\section{Results:-}

The drugs Patoladi Ghanvati along with some indigenous drugsprovided a highly significant $(\mathrm{P}<0.001)$ effect on the symptom; periodicity of pain, nausea and vomiting, pain in relation to food, epigastric pain and acid regurgitation.

The relief percentage of the drug on periodicity of pain was $91.42 \%$, significant improvement in nausea and vomiting was $93.44 \%$. Effect of pain in relation with food was $92.42 \%$. There was $90 \%$ relief in epigastric pain. Maximum improvement i.e. $97.43 \%$ was observed in acid regurgitation.

\begin{tabular}{|c|c|c|c|c|c|c|c|c|c|}
\hline \multirow[t]{2}{*}{$\mathrm{S}$ y $\mathrm{mptom} \mathrm{s}$} & $\mathrm{M} \quad \mathrm{e}$ & $\mathrm{a}$ & \multirow{2}{*}{$\begin{array}{l}\text { Mean diff. } \\
(\mathrm{X})\end{array}$} & \multirow[t]{2}{*}{$\%$ Relief } & \multirow[t]{2}{*}{ S D } & \multirow[t]{2}{*}{$\mathrm{S} \quad \mathrm{E}$} & \multirow[t]{2}{*}{ 't' value } & \multirow[t]{2}{*}{$\mathrm{P}$ value } & \multirow[t]{2}{*}{ Significance } \\
\hline & $\mathrm{T}$ & & & & & & & & \\
\hline Periodicity of pain & 2.33 & & 2.13 & $91.42 \%$ & 0.43 & 0.07 & 26 & $<0.001$ & $\mathrm{H}$ \\
\hline Nausea \& vomiting & 2.03 & 0.13 & . 9 & $93.44 \%$ & 80 & 0.14 & 12 & $<0.001$ & $\mathrm{H}$ \\
\hline Pain in relation with food & 2.2 & 0.16 & 03 & $92.42 \%$ & 0.49 & 0.08 & 22. & $<0.001$ & $\mathrm{H}$ \\
\hline Epigastric pain & 2 & 0. & . 8 & $900 \%$ & 0.40 & 0.07 & 24 & $<0.001$ & $\mathrm{H}$ \\
\hline Acid Regurgitation & 2.6 & 0.06 & 2.53 & $97.43 \%$ & 0.50 & 0.09 & 27.34 & $<0.001$ & $\mathrm{H}$ \\
\hline
\end{tabular}

Overall Assessment of the Results - After completion of the treatment $60 \%$ of the patients (18) got cured, 33.33\% of the patients (10) got markedly improvement \& $6.66 \%$ of the patients (2) showed moderate improvement.

\begin{tabular}{|c|c|c|c|}
\hline Sr. No. & E f f e c t o f $\quad$ t $h$ e $\quad r$ a $p \quad y$ & Number of patients & $P$ e $r$ c e $n$ t a g e \\
\hline 1 & $\mathrm{C} \quad \mathrm{u}$ & 18 & $\begin{array}{lll}6 & 0 & \%\end{array}$ \\
\hline 2 & $\mathrm{I} m \mathrm{pr} o \mathrm{v}$ e $\mathrm{e} \mathrm{n} \mathrm{t}$ & 0 & . 3 \\
\hline 3 & Moderate I m p rove me $\mathrm{nt}$ & 2 & $\%$ \\
\hline 4 & 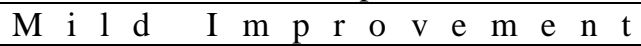 & 0 & $\%$ \\
\hline 5 & $\begin{array}{llllllll}\mathrm{N} & \mathrm{o} & \mathrm{t} & \mathrm{c} & \mathrm{u} & \mathrm{r} & \mathrm{e} & \mathrm{d}\end{array}$ & 0 & $\%$ \\
\hline
\end{tabular}




\section{Discussion:-}

Selection of problem - The present time is the era of fast food, irregularities in daily meal-time, sedentary life style and mental stress. All these factors ultimately disturb the digestive system resulting in the manifestation of various diseases. Among them is Parinaam Shoola.

Every year over three lacks people round the world have ulcer related surgeries, because of persistent symptoms or complications. All the operations for Duodenal Ulcer have achieved their aim to some extent but with varying degree of morbidity, mortality and post-operative side effects. Because of this condition, the person always remains in the state of discomfort.

The treatment which has been advocated for this condition is usually symptomatic and has its own limitations. Dietary modification in such patients have proved to be successful, however they are of limited value in the chronic progressive nature of the disease. Various drugs have been used for the treatment of Parinaam Shoola in Ayurvedic system; however, till date no remedy is available to make a permanent long lasting therapy.

The present study is the first work on the effect of Patoladi Ghanvati in Parinaam Shoola and it was planned with holy aim to find out a beneficial, safe and cost effective drug in the management of Parinaam Shool.

\section{Probable mode of action of Patoladi Ghan Vati:-} Ayurvedic Aspect:-

1. Since Vata is the most predominant and most potent factor in initiating and maintaining the pathogenesis of Parinaam Shoola, so Vatanulomana property of Murva, Mulethi, Sunthi, Patola and Guduchi might probably helped in disease regression.

2. Pitta dosha is taken as the predominant Dosha in Parinaam Shoola, so we can say that Pittasarak property of Guduchi, Kutki, Mulethi, Nimb, Chitrak, Murva and Patola might helped in removing Saam Pitta.

3. Parinaam Shoola is a Rasaja Vyadhi and according to our ancient literature Langhan is one of the treatments of Rasaja vyadhi. Ingestion of Pachak Aushdhi comes under the process of Langhan. Guduchi, Sunthi, Patha, Chitrak and Murva might help in proper digestion.

4. Guduchi, Kutki, Sunthi, Patha, Chitrak, Murva and Patola, because of their Deepan activity might help in stimulating the appetite.

5. Shoola, in case of Parinaam Shoola, might be reduced due to Udar Shoola Shamak property ofChitrak, Mulethi, Patha and Sunthi.

Modern Aspect:-

1. Ulcer regression may be because of Anti-ulcer activity of Mulethi,Neem, Raktachandan, Patha, Sunthi and Chitrak.

2. Since there is a strong causal relation between H. pyloriinfection and duodenal ulcer, hence Anti $H$. pylori activity of Mulethi, Sunthi and Honey probably stopped the disease progression.

3. Because of Anti-spasmodic property of Chitrak, Mulethi, Patha and Sunthi, it probably helped in reducing and/ or pulverizing the epigastric pain, periodicity of pain, pain in relation with food and hunger pain.

4. Anti-inflammatory activity of Guduchi, Neem, Patola and Sunthi probably helped in checking the progress of the disease.

5. The relationship between stress and ulcers is so strong that people with ulcers should be treated for psychological conditions. So, anti-stress effect of Neem, Patola, Swetachandan and Guduchi might help in alleviating stress.

6. Infection with H.pylori is associated with generation of reactive oxygen molecules, which leads to oxidative stress in the gastric mucosa, so anti-oxidative therapy stimulates the healing of duodenal ulcers. Anti-oxidative property of Patola, Sunthi, Kutki, Mulethi, Patha and Chitrak probably helped in checking the progression of the disease.

\section{Conclusion:-}

The following conclusions can be drawn from the observations of the present study-

1. According to present knowledge the normal functioning of the Agni, Pachaka Pitta means the secretoenzymatic functioning of gastrointestinal tract which is deranged in this disease. 
2. The etiological factors mentioned are to be applied to the present day food habits for pin pointing the causative factors. The irresistible stress and strain of this present era are related with the pathogenesis of this disease. Present lifestyle that has disturbed the food habits gives rise to Agnimandya, Vidagdhajirna and finally leads to Parinaam Shoola.

3. From this study it can be concluded that non compliance of code of healthy diet selection and eating habits play a major role in causation of the disease. Hence we can say that code and conduct of healthy eating is important to achieve early and better result of the treatment as Nidana Parivarjana.

4. The drug under trial, Patoladi Ghan Vati was effective alleviating the symptoms of Parinaam Shoola. It was observed that the drug is especially effective in early cases of Parinaam Shoola. This beneficial effect of trial drug may be due to its Deepan, Pachan, Pitta-sarak, Udarshool-nashak, Vatanulomak, Anti-inflamatory, AntiUlcer, Anti-oxidant, Anti-Stress and Anti-Spasmodic properties.

5. On the basis of above mentioned facts, thoughts, data and results, it can be concluded that Patoladi Ghanvati is definitely effective in the management of Parinaam Shoola, most importantly with life style and dietary modification.

The study was conducted for a limited period and in a limited number of patients, hence it is suggested that to reveal more about efficacy of the trial drug and its satisfactory therapeutic response, the trial must be taken in a large number of heterogeneous population, so that more reliable statistical data can be obtained.

\section{References:-}

1. Sonnenberg A. Time trends of ulcer mortality in Europe. Gastroenterology 2007; 132:2320.

2. The American Journal of Gastroenterology (2002) 97, 2950-2961.

3. Ulcer, Diagnosis and Treatment - CDC Bacterial, Mycotic Diseases.

4. F. I. Tovey, Division of Surgery and Interventional Science, University College, London, UK and K. D. Bardhan, Department of Gastroenterology, Rotherham General Hospital, UK. 24 OCT 2012.

5. Sachs G, Shin JM, Vagin O et al. Current trends in the treatment of upper gastrointestinal disease. Best Practice and Resercag Clinical Gastroenterology. 2002; 16 (6): 835-849.

6. A concise Textbook of Surgry, S.Das, published by Dr. Somen Das, Kolkata, $9^{\text {th }}$ Edition 2016.

7. Tsoi KK et. Al. Causes of mortality in patients with peptic ulcer bleeding: a prospective cohort study of 10,428 cases. Am J Gastroenterol. Jan 2010;105(1):84-9.

8. Hu PJ, Li YY et al. Gastric atrophy and regional variation in upper gastrointestinal disease. Am J Gastroenterol 1995; 90:1102.

9. Pietroiusti A, Luzzi I, Gomez MJ, Magrini A, Bergamaschi A, Forlini A, et al. Helicobacter pylori duodenal colonization is a strong risk factor for the development of duodenal ulcer. Aliment Pharmacol Ther. Apr 1 2005;21(7):909-15.

10. Schwartz's principles of surgery, 9th Edition,F. Charles Brunicardi, Dana K. Anderson,David L. dunn.

11. Choudhary S.K., Concise Medical Physiology, New central book agency, $5^{\text {th }}$ Edition.

12. January 1961, Volume 6, Issue 1, pp 68-75, The American journal on digestive diseases ,Complications of duodenal ulcer

13. The Washington Manual of Surgery,6th Edition,Mary E.Klingensmith,Abdulhameed Aziz,Ankit Bharat

14. Madhava, Madhav Nidan with Madhukosha Vyadkhya by Vijayrakshita and Sri Kanta Dutta by Sudarshan Shastri, Choukhambha Sanskrit Sansthan, Varanasi - 26/16.

15. Madhav Nidan- Chapter 26, Atha Shooka Parinamshoola Annadravashoola Nidanam, Choukhambha Sanskrit Sansthan, Varanasi.

16. Ambikadutta Sastri, Sushrut Samhita, Ayurvedatatva Sandeepika, Part I, $8^{\text {th }}$ Edition, Choukhambha Sanskrit Sansthan, Varanasi. Patoladi Gana 38/33-34. 